\title{
Transposed Brachial-Basilic Arteriovenous Fistula for Vascular Access in Japan
}

\author{
Juno Deguchi, MD, PhD and Osamu Sato, MD, PhD
}

As more than 320,000 patients are currently receiving hemodialysis treatment in Japan, the creation and maintenance of hemodialysis access is a major concern. The national guidelines recommend autogenous arteriovenous hemodialysis, and the brachial-basilic arteriovenous fistula has been the focus of attention, because the need for secondary, tertiary, or even more vascular access is growing. Although favorable results have been reported in terms of patency and access-related complication, this fistula involves various unsolved or controversial issues, with limitations including complex procedures, which might contribute to the lower prevalence at this point in Japan. This review addresses those issues and discusses the role of fistula in Japan.

Keywords: arteriovenous fistula, basilic vein, vascular access

\section{Introduction}

The number of patients with end-stage renal disease (ESRD) dependent on intermittent hemodialysis has exceeded 320,000 and is still increasing in Japan. ${ }^{1)}$ The development of hemodialysis has improved the longterm survival of patients and has increased availability of dialysis, including to older or diabetic individuals who have poor autogenous vessels. ${ }^{2)}$ The need for secondary, tertiary, or even more vascular access is thus growing. Because autogenous arteriovenous fistulas (AVFs) offer better patency rates with fewer complications and lower mortality rates compared with other options for vascular

Department of Vascular Surgery, Saitama Medical Center, Saitama Medical University, Kawagoe, Saitama, Japan

Received: January 16, 2018; Accepted: March 9, 2018 Corresponding author: Juno Deguchi, MD, PhD. Department of Vascular Surgery, Saitama Medical Center, Saitama Medical University, 1981 Kamoda, Kawagoe, Saitama 350-8550, Japan Tel: +81-49-228-3400, Fax: +81-49-228-3462

E-mail: jdegu-tky@umin.ac.jp

(cc) BY-NC-SA (9)2018 The Editorial Committee of Annals of Vascular Diseases. This article is distributed under the terms of the Creative Commons Attribution License, which permits use, distribution, and reproduction in any medium, provided the credit of the original work, a link to the license, and indication of any change are properly given, and the original work is not used for commercial purposes. Remixed or transformed contributions must be distributed under the same license as the original. access, including prosthetic grafts (arteriovenous graft; AVG) or catheters, ${ }^{2-4)}$ a structured approach to optimize the use of autogenous veins in the upper limbs seems imperative for vascular access. ${ }^{5)}$

Transposed brachiobasilic arteriovenous fistula (TBBAVF) was introduced by Dagher in $1986^{6}$ ) and has shown many favorable results in terms of patency and accessrelated complication. ${ }^{7-9)}$ Anatomically, the basilic vein is usually longer and has thicker wall than the cephalic vein. ${ }^{10,11)}$ This vessel is also relatively preserved from repeated cannulation of blood draws and intravenous catheter. Despite those theoretical advantages, the basilic vein needs to be translocated for cannulation in chronic hemodialysis therapy. On the other hand, AVF using the transposed basilic vein involves various unsolved or controversial issues regarding indication of staged operation, means of elevation, and timing of creation compared with the fistula using a prosthetic graft. ${ }^{12-14)}$ Moreover, the transposed fistula has some limitations, including complex procedures, longer maturation time for cannulation and non-enthusiastic recommendation in the Japanese guideline for vascular access, ${ }^{15)}$ which might be causes of the lower prevalent at this point in Japan.

The purpose of this study was to address the issues and controversies surrounding TBBAVF and to discuss its potential role for creation and management of vascular access in Japan.

\section{Use of Vascular Access in Japan}

Annual reports from the United States Renal Data System indicated that the number of treated cases of ESRD in Japan in 2014 was 2,505 per million population (3,287 in men and 1,764 in women), making Japan the country with the second highest prevalence. ${ }^{16)}$ For the record, 96.9\% of the Japanese dialysis patients selected hemodialysis as a renal replacement therapy, and only approximately 1,500 renal transplantations are performed annually in Japan. ${ }^{17)}$ The mean survival time of Japanese patients after first-ever hemodialysis is 7.3 years, one of the longest in the world. ${ }^{1)}$ Patients with hemodialysis for more than 10 years account for up to $27.8 \%$, and those with long-term hemodialysis are increasing in number, whereas patients 
with hemodialysis therapy for 5 years or less account for $47.3 \%$ of all the hemodialysis population in Japan. ${ }^{1)}$ At the same time, Japanese hemodialysis patients tend to be older and show a stronger association with diabetes, with the average age of 67.2 years and $37.6 \%$ of all hemodialysis with diabetes in 2013.1) AVFs are recognized as a better choice for most hemodialysis patients compared with prosthetic implants such as artificial grafts or central venous catheters (CVCs) $)^{4,18}$ because of complications including infection. Therefore, it is worthy of special mention that Japan showed one of the highest rates of AVF use, in more than $90 \%$ of hemodialysis patients, according to the Dialysis Outcomes and Practice Patterns Study from the United States. ${ }^{19)}$ Moreover, along with 9\% using artificial graft (AVG), the most notable feature was that less than $1 \%$ of the patients were undergoing dialysis with CVC in Japan. ${ }^{19}$ In addition, among incident first-ever hemodialysis patients, AVF use in Japan is also one of the highest rates in the world, with more than $80 \%$ using AVF, comparing $65 \%$ in Germany and $38 \%$ in the United States. ${ }^{19)}$ These results indicate that continuing efforts by Japan dialysis units are avoiding CVC and optimizing vascular access use from first-ever hemodialysis treatment. ${ }^{20)}$ Despite such efforts, development of AVF as a vascular access still faces a hostile situation in Japan, because a substantial proportion of patients lack good superficial vessels, and such patients are increasing along with increases in elderly and diabetes patients. ${ }^{21)}$

\section{Anatomy of the Basilic Vein}

The basilic vein, originating on the medial side of dorsal venous network, runs along the medial aspect of the forearm and connects with the medial cubical vein in the elbow. This vessel runs up the ulnar aspect of the upper arm and pierces into the brachial fascia to connect with the brachial vein to form the axillary vein. In the upper arm, the basilic vein runs along with the medial antebrachial cutaneous nerve. However, several variations in basilic vein anatomy exist. Anaya-Ayala et al. described three types of brachial-basilic vein connections based on ultrasound scanning: type 1 (66\%), basilic-brachial junction at the axillary level; type $2(17 \%)$, basilic-brachial junction at the mid or lower portion of the upper arm with the duplication of the brachial vein; and type $3(17 \%)$, basilic-brachial junction at the mid or lower portion of the upper arm with no duplication of the brachial vein. ${ }^{22)}$ Hyland analyzed basilic-brachial vein using preoperative venography for vascular access and reported early basilicbrachial vein confluence in $44 \%$ and multi-junctions of basilic-brachial vein in 7\%. ${ }^{23)}$ Simply put, more than onethird of the upper limbs show a low junction of basilicbrachial confluence.

\section{Preoperative Evaluation}

Preoperative imaging by ultrasound improves the outcomes of AVF creation. ${ }^{24,25)}$ Such evaluations should include the veins and arteries throughout the forearm and upper arm, with assessment of their diameter and quality. Although vein diameter over $2.5 \mathrm{~mm}$ has been recommended for AVF maturation, ${ }^{26)}$ some authors favor vein diameter over $3.0 \mathrm{~mm}$ for TBBAVF ${ }^{27,28)}$ because the basilic vein needs to be mobilized with discission of all tributaries, which results in increasing peripheral resistance. The diameter of the brachial artery should be over $2.0 \mathrm{~mm}$ without a reduced pressure gradient or Doppler waveform that would suggest arterial inflow stenosis. These assessments would help identify anatomical variations of the arteries and veins.

\section{Surgical Technique}

Although Hossny classified the techniques in creating brachiobasilic AVF into three types (one-stage transposition, one-stage elevation, and two-stage elevation), ${ }^{29)}$ these procedures accepted regarding creating TBBAVF along with various technical modifications; one-stage transposition, one-stage elevation, two-stage transposition, or two-stage elevation procedures (Fig. 1).

One-stage procedure: This procedure is an original method for TBBAVF, comprising arteriovenous anastomosis and anterior and superficial relocation of the basilic vein. ${ }^{6}$ Under an interscalene nerve block with or without intravenous sedation, the basilic vein is exposed from the ulnar aspect of the forearm to the axilla with a continuous or interrupted longitudinal incision. All branches of the basilic vein should be ligated and mobilized proximally to the confluence with the brachial vein. The axillary vein at the confluence should also be mobilized to facilitate the smooth transposition of the basilic vein. The antebrachial subcutaneous nerve, running along with the basilic vein in the upper arm, is carefully spared. The basilic vein is gently distended with heparinized saline to eliminate distortion. The brachial artery is then explored at the elbow. The mobilized basilic vein is transposed to the anterior arm inside a subcutaneous pocket by direct dissection (transposition). Korkut and Kosem recently described transposition of mobilized basilic vein with the use of tunneling device under separate skin incision. ${ }^{30)}$ Although transposition is a common way of superficial relocation, a few groups prefer primary elevation for TBBAVF, simply comprising mobilization of basilic vein superficially (elevation). ${ }^{31,32)}$ In their opinion, elevation may reduce the risk of kinking or twisting of the fistula. Special attention should be paid to ensure that the vein shows a smooth curve near the axilla without twisting. After systemic 


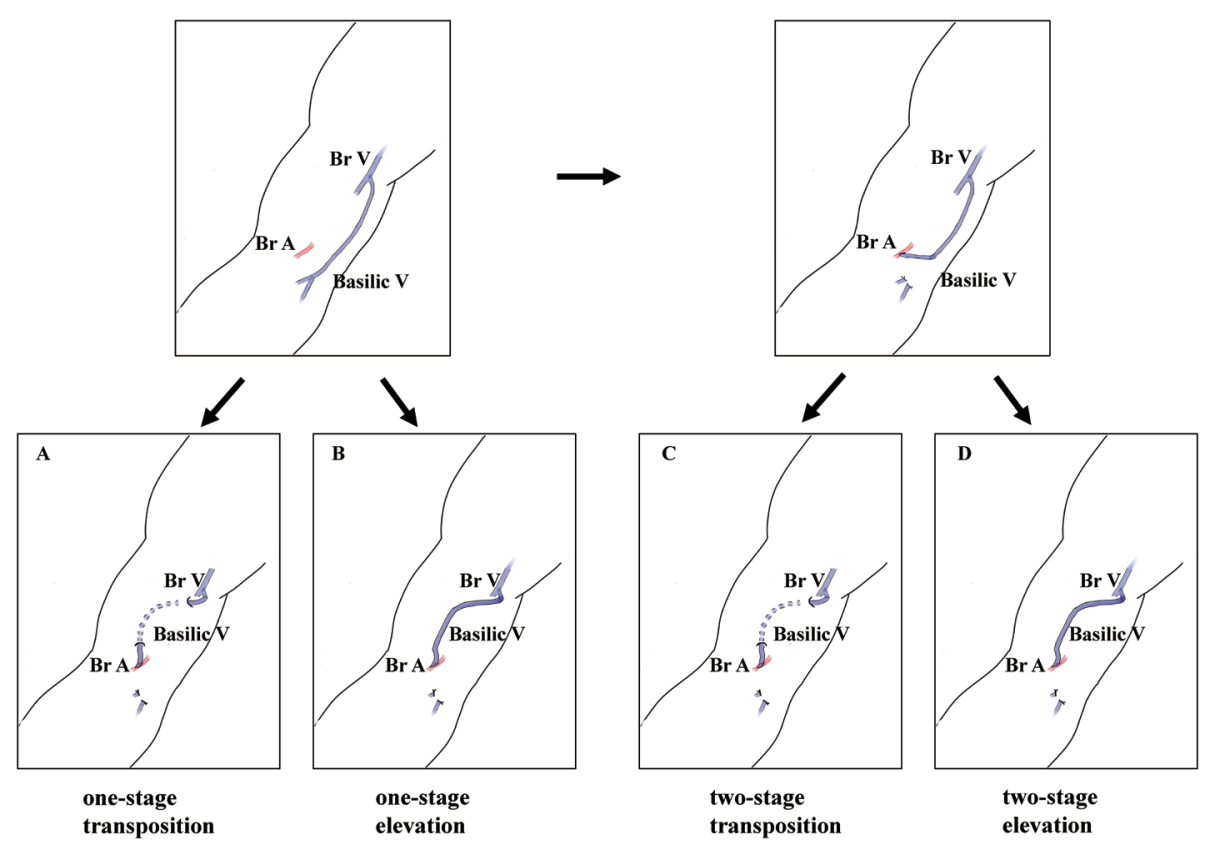

Fig. 1 Schema of types of TBBAVF. One-stage procedure comprises arteriovenous anastomosis and anterior and superficial relocation of the basilic vein in one operation. Two-stage procedure is a creation of arteriovenous fistula followed by relocation of the basilic vein at different times. Transposition is a relocation with tunneling using tunneler device and elevation indicates moving superficially without tunneling. (A) one-stage transposition; (B) one-stage elevation; (C) two-stage transposition; (D) twostage elevation.
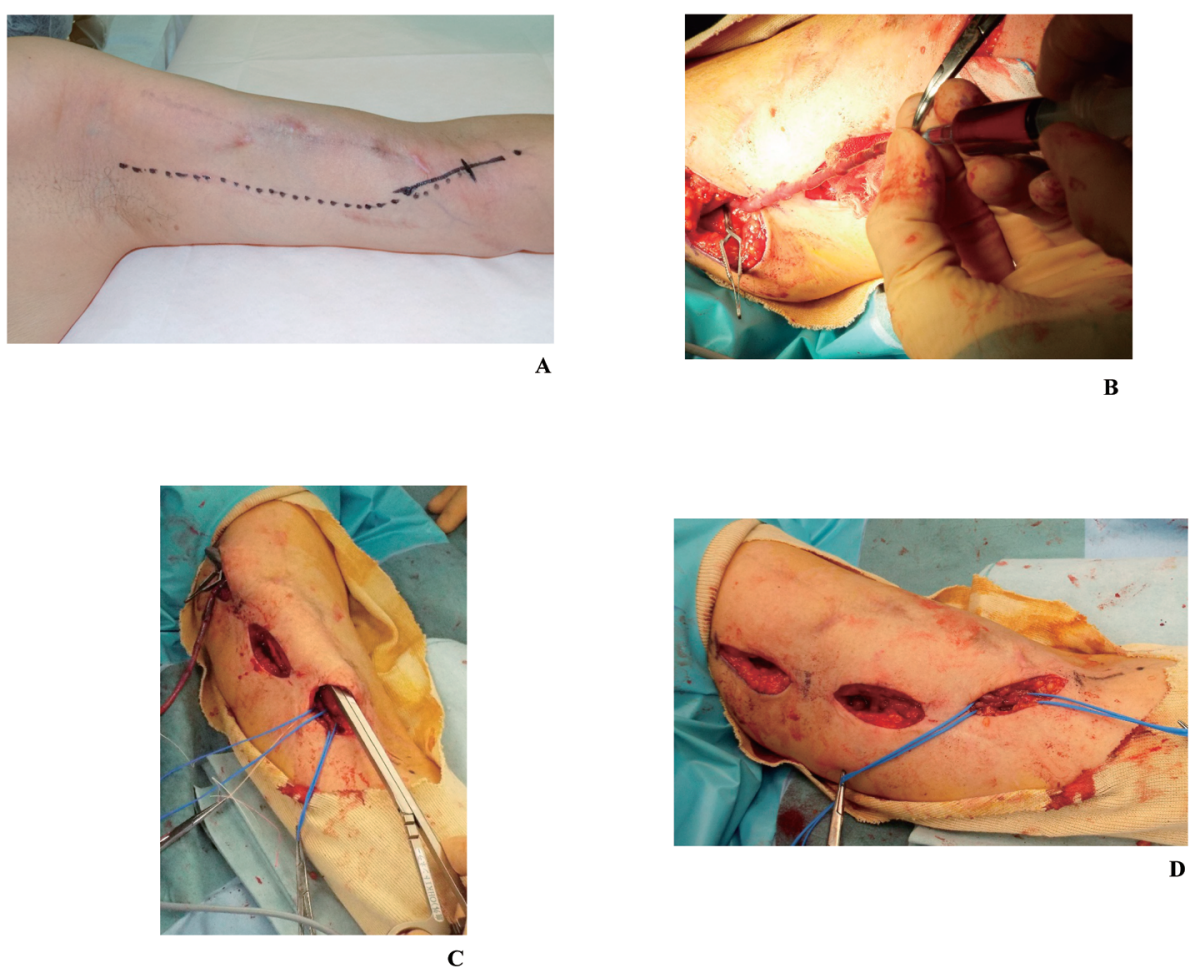

Fig. 2 Illustration of surgical procedure of one-stage transposition. (A) preoperative marking; (B) distention of the basilic vein with heparinized saline to eliminate distortion; (C) tunneling of mobilized basilic vein; (D) completion of anastomosis between the transposed basilic vein and the brachial artery. 
anticoagulation with heparin sulfate, a vascular clamp is made with a $5 \mathrm{~mm}$ arteriotomy in the brachial artery and an end-to-side anastomosis is constructed using a 6-0 or 7-0 polypropylene suture. The course of the vein should be examined closely, and the presence of a thrill is a key to creating successful fistula (Fig. 2).

Two-stage procedure: The first stage of this procedure is simply the creation of the AVF, followed by the second stage of elevation or transposition. ${ }^{33,34)}$ The first stage includes an end-to-side anastomosis between the basilic vein and the brachial artery in the elbow. Several weeks later, at the time of the basilic vein maturation, the basilic vein is mobilized from the previous anastomosis site to the confluence with the brachial vein through continuous or interrupt longitudinal incision. The two-stage method may facilitate placement of pressure on smaller ramifications and reduce the risk of surgical flaw at the time of mobilization. With the creation of a pocket in the subcutaneous tissue, the basilic vein is relocated superficially and anterolaterally for "elevation," ${ }^{35)}$ or the fistula vein is transected, then routed via the superficial tunnel anterolaterally and re-anastomosed, representing "transposition" instead of simple elevation. Although elevation and transposition are confused in some reports, transposition method seems to be more prevalent because denuded area can be reduced in the second stage. Wang et al. recently compared twostage elevation with two-stage transposition and found that two-stage elevation is a reliable approach because of better primary patency and reduced need for salvage interventions to the fistulas. ${ }^{36)}$ The interval between the first and second operations is varied from 3 to 8 weeks depending on the maturation criteria of the basilic vein.

Other techniques: Several surgical modifications have been described, usually comprising reduced tissue dissection to avoid skin complications. ${ }^{37-40)}$ Using endoscopic vein-harvesting system with sealing and division of the branches of the basilic vein, several small incision techniques offer comparable results with those of the regular open method.

\section{Criteria of Maturation}

Without standard criteria for fistula maturation, there are no specific criteria of maturation for TBBAVF. In Japan, early cannulation tends to be performed with a minimal access flow rate of $160 \mathrm{~mL} / \mathrm{min}$ for radial-cephalic AVF, compared with $200 \mathrm{~mL} / \mathrm{min}$ in Europe and $300 \mathrm{~mL} / \mathrm{min}$ in the United States. According to the KDOQI 2006 guidelines, functional access can be defined for fistula diameter $>6 \mathrm{~mm}$, access flow $>600 \mathrm{~mL} / \mathrm{min}$ and the depth $<6 \mathrm{~mm} .{ }^{18)}$ Arroyo et al. described the following criteria for maturation in TBBAVF: fistula vein diameter $>6 \mathrm{~mm}$, estimated access flow $>400 \mathrm{~mL} / \mathrm{min}$ without stenosis. ${ }^{41)}$
Lioupis' criteria were fistula vein diameter $>3.5 \mathrm{~mm}$ and access flow $\left.>600 \mathrm{~mL} / \mathrm{min} .{ }^{42}\right)$ Because Voormolen et al. identified immature AVF as providing insufficient access flow at 6 weeks after creation ${ }^{43)}$ and the vascular access guideline in Japan showed below $200 \mathrm{~mL} / \mathrm{min}$ of access flow as insufficient flow, more than $300 \mathrm{~mL} / \mathrm{min}$ of access flow 6 weeks after creation would be minimum for TBBAVF. Rao et al. reported a high failure rate for maturation in TBBAVF, up to $38 \% .{ }^{44)}$ However, other reports have usually described lower maturation around 10-20\%. Hakaim et al. compared radiocephalic, brachiocephalic, and TBBAVFs, reporting superior maturation of TBBAVF in diabetic patients. ${ }^{45)}$

\section{TBBAVF vs. AVG}

Several reports have compared TBBAVF with prosthetic vascular access. As fistulas using prosthetic graft (AVG) show wide variation, including brachial-antecubital forearm loop or brachial-axial straight with several prosthetic graft materials, methods should be tested one by one when comparing between TBBAVF and AVG in each manuscript. Table 1 summarizes the main outcomes reported in various studies. ${ }^{42,46-62)}$ Chemla and Morsy found that TBBAVF offered a better patency rate with greater costeffectiveness compared with brachio-axillary AVG. ${ }^{53)}$ Chue et al. studied 122 Asian patients and reported that TBBAVF provided superior patency and required fewer salvage interventions compared with forearm AVG. ${ }^{62)}$ However, recent studies showed comparable patency between AVG and TBBAVF and have favored the use of prosthetic grafts in specific groups like elderly patients, because of the short cannulation period. ${ }^{42,55,61)}$ Overall, utilization of TBBAVF is associated with reduced risk of access failure, whereas AVG represents the preferred option for elderly patients. ${ }^{63)}$

\section{One-Stage vs. Two-Stage Approach}

The choice between one- and two-stage approaches has been a subject of focus in creating TBBAVF. To date, two randomized reports have compared one- and two-stage procedures, showing higher maturation and better 1 year patency in the two-stage procedure. ${ }^{64,65)}$ However, both studies have critical limitations, including small sample size $(\mathrm{n}=16)$ in the study by Kakkos et al. ${ }^{65)}$ and short follow-up period in El Mallah's study, ${ }^{64)}$ with considerable disparity in maturation rate and patency compared with their former report. ${ }^{65,66)}$ Data on the features of one- or two-stage procedures of TBBAVF have been accumulated from several retrospective studies. ${ }^{67)}$ Mixed opinions have been reported regarding functional patency rate, with some studies describing better patency rates under the 
Table 1 List of studies compared TBBAVF with AVG

\begin{tabular}{|c|c|c|c|c|c|c|c|c|c|}
\hline First author & Year & Study & & $\begin{array}{l}\text { Number } \\
\text { of } \\
\text { patients }\end{array}$ & $\begin{array}{l}\text { Patency at } \\
1 \text { year } \\
\text { (primary/ } \\
\text { secondary) }\end{array}$ & $\begin{array}{l}\text { Patency at } \\
2 \text { years } \\
\text { (primary/ } \\
\text { secondary) }\end{array}$ & $\begin{array}{l}\text { Type of } \\
\text { prosthesis }\end{array}$ & Main complications & Comment \\
\hline \multirow[t]{2}{*}{ Coburn } & 1994 & Retrospective & TBBAVF & 59 & $90^{*}$ & $86 *$ & & Infection $3.4 \%$, bleeding $6.8 \%$ & \\
\hline & & & AVG & 47 & $70 / 87$ & $49 / 64$ & PTFE & Infection $16.1 \%$, bleeding $1.6 \%$ & \\
\hline \multirow[t]{2}{*}{ Matsuura } & 1998 & Retrospective & TBBAVF & 30 & & 70 & & Infection $0 \%$ & \\
\hline & & & AVG & 67 & & 46 & $\begin{array}{l}\text { Brachio-axillary, } \\
\text { PTFE }\end{array}$ & Infection $10 \%$ & \\
\hline \multirow[t]{2}{*}{ Gibson } & 2001 & Retrospective & TBBAVF & 181 & & $27.7 / 61.5$ & & & $\begin{array}{l}\text { Benefit for women } \\
\text { and patients with } \\
\text { access failure }\end{array}$ \\
\hline & & & AVG & 64 & & $24.6 / 39.8$ & & & \\
\hline \multirow[t]{2}{*}{ Oliver } & 2001 & Retrospective & TBBAVF & 59 & 164 & & & $\begin{array}{l}\text { Infection } 2 \% \text {, poor maturation } \\
6 \% \text {, arm swelling } 3 \%\end{array}$ & \\
\hline & & & AVG & 82 & 162 & & PTFE & $\begin{array}{l}\text { Infection } 13 \% \text {, poor maturation } \\
1 \% \text {, arm swelling } 6 \%\end{array}$ & \\
\hline \multirow[t]{2}{*}{ Weale } & 2007 & Retrospective & TBBAVF & 71 & $45.3 / 53.6$ & $40.0 / 50.9$ & & Infection $0 \%$ & \\
\hline & & & AVG & 114 & $56.4^{*}$ & $43.2^{*}$ & Brachio-axillary & Infection $6.2 \%$ & \\
\hline \multirow[t]{2}{*}{ Kakkos } & 2008 & $\begin{array}{l}\text { Controlled } \\
\text { comparative }\end{array}$ & TBBAVF & 76 & $\begin{array}{c}46 / 87 \\
\text { (primary assist, } \\
82 \% \text { ) }\end{array}$ & & & $\begin{array}{l}\text { Infection } 0 \% \text {, bleeding } 9.8 \% \text {, } \\
\text { venous hypertension } 15 \%\end{array}$ & \\
\hline & & & AVG & 41 & $\begin{array}{c}50 / 88 \\
\text { (primary assist, } \\
70 \% \text { ) }\end{array}$ & & $\begin{array}{l}\text { Brachio-axillary, } \\
\text { Vectra }\end{array}$ & $\begin{array}{l}\text { Infection } 6.6 \% \text {, bleeding } 2.6 \% \text {, } \\
\text { venous hypertension } 1.3 \%\end{array}$ & \\
\hline \multirow[t]{2}{*}{ Keuter } & 2008 & Randomized & TBBAVF & 52 & $\begin{array}{c}46 / 89 \\
\text { (primary assist, } \\
87 \% \text { ) }\end{array}$ & & & $\begin{array}{l}\text { Incidence rate of complica- } \\
\text { tions: } 1.6 \text { per patient-year }\end{array}$ & \\
\hline & & & AVG & 53 & $\begin{array}{c}22 / 85 \\
\text { (primary assist, } \\
71 \% \text { ) }\end{array}$ & & $\begin{array}{l}\text { Forearm loop, } \\
\text { PTFE }\end{array}$ & $\begin{array}{l}\text { Incidence rate of complica- } \\
\text { tions: } 2.7 \text { per patient-year }\end{array}$ & \\
\hline \multirow[t]{2}{*}{ Chemla } & 2008 & Retrospective & TBBAVF & 34 & $73 / 93$ & $69 / 85$ & & & $\begin{array}{l}\text { TBBAVF: } \\
\text { cost-effective }\end{array}$ \\
\hline & & & AVG & 42 & $61 / 70$ & $54 / 62$ & $\begin{array}{l}\text { Brachio-axillary, } \\
\text { PTFE (Intering) }\end{array}$ & & \\
\hline \multirow[t]{2}{*}{ Pflederer } & 2008 & Retrospective & TBBAVF & 161 & $58 / 97$ & $44 / 97$ & & $\begin{array}{l}\text { Infection rate: } 0.07 \text { per patient- } \\
\text { year }\end{array}$ & \\
\hline & & & AVG & 285 & $18 / 66$ & $5 / 54$ & Loop, straight & $\begin{array}{l}\text { Infection rate: } 0.23 \text { per patient- } \\
\text { year }\end{array}$ & \\
\hline \multirow[t]{2}{*}{ Torina } & 2008 & Retrospective & TBBAVF & 42 & $\begin{array}{c}45 / 74 \\
\text { (primary assist, } \\
74 \%)^{* *}\end{array}$ & & & & \\
\hline & & & AVG & 94 & $\begin{array}{c}50 / 78 \\
\text { (primary assist, } \\
63 \% \text { ) }\end{array}$ & & & & \\
\hline \multirow[t]{2}{*}{ Maya } & 2009 & Prospective & TBBAVF & 67 & & $/ 55$ & & Primary access failure: $15 \%$ & \\
\hline & & & AVG & 289 & & 145 & & Primary access failure: $18 \%$ & \\
\hline \multirow[t]{2}{*}{ Woo } & 2009 & Retrospective & TBBAVF & 119 & $65^{*}$ & & & $\begin{array}{l}\text { Infection } 1.6 \% \text {, bleeding } 3.7 \% \text {, } \\
\text { steal } 3.2 \%\end{array}$ & \\
\hline & & & AVG & 168 & $48^{*}$ & & $\begin{array}{l}\text { Upper arm, } \\
\text { PTFE }\end{array}$ & $\begin{array}{l}\text { Infection } 7.9 \% \text {, bleeding } 1.8 \% \text {, } \\
\text { steal } 4.9 \%\end{array}$ & \\
\hline \multirow{3}{*}{$\begin{array}{l}\text { Sala } \\
\text { Almonacil }\end{array}$} & 2011 & Retrospective & TBBAVF & 36 & $50.4 / 50.4$ & $45.8 / 45.8$ & & Infection $0 \%$, access problem & \\
\hline & & & & & & & & $13.8 \%$ & \\
\hline & & & AVG & 40 & $64.3 / 67.7$ & $46.2 / 54.2$ & $\begin{array}{l}\text { Brachio-axillary, } \\
\text { PTFE }\end{array}$ & $\begin{array}{l}\text { Infection } 10 \% \text {, access problem } \\
5 \%\end{array}$ & \\
\hline \multirow[t]{2}{*}{ Lioupis } & 2011 & Retrospective & TBBAVF & 45 & & $51^{* * *}$ & & & $\begin{array}{l}\text { Access } \\
\text { intervention: higher } \\
\text { in AVG group }\end{array}$ \\
\hline & & & AVG & 48 & & $55^{* * *}$ & $\begin{array}{l}\text { Brachio-axillary, } \\
\text { PTFE (Flixene) }\end{array}$ & & \\
\hline
\end{tabular}


Table 1 Continued

\begin{tabular}{|c|c|c|c|c|c|c|c|c|c|}
\hline First author & Year & Study & & $\begin{array}{c}\text { Number } \\
\text { of } \\
\text { patients }\end{array}$ & $\begin{array}{c}\text { Patency at } \\
1 \text { year } \\
\text { (primary/ } \\
\text { secondary) }\end{array}$ & $\begin{array}{l}\text { Patency at } \\
2 \text { years } \\
\text { (primary/ } \\
\text { secondary) }\end{array}$ & $\begin{array}{c}\text { Type of } \\
\text { prosthesis }\end{array}$ & Main complications & Comment \\
\hline \multirow[t]{3}{*}{ Morosetti } & 2011 & Retrospective & TBBAVF & 30 & $61 / 76$ & $60 / 66$ & & & \\
\hline & & & AVG & 27 & $32 / 52$ & $21 / 34$ & Polyester & & \\
\hline & & & & & & & Omniflow & & \\
\hline \multirow[t]{2}{*}{ Basel } & 2011 & Retrospective & TBBAVF & & & 67 & & & \\
\hline & & & AVG & & & 32 & & & \\
\hline \multirow[t]{2}{*}{ Davoudi } & 2013 & Randomized & TBBAVF & 30 & 76.3 & & & $\begin{array}{l}\text { Similar thrombosis or infection } \\
\text { rate }\end{array}$ & \\
\hline & & & AVG & 30 & 70 & & Brachio-axillary & & \\
\hline \multirow[t]{2}{*}{ Chue } & 2016 & Retrospective & TBBAVF & & $73.2 / 71.8$ & & & & \\
\hline & & & AVG & & $34.1 / 54.3$ & & $\begin{array}{l}\text { Forearm loop, } \\
\text { PTFE }\end{array}$ & & \\
\hline
\end{tabular}

*: secondary not described; **: two-stage procedure; ***: secondary patency at 18 months

two-stage approach and some showing comparable patency rates in both groups. ${ }^{66,68,69)}$ Vrakas et al. reported better 2 year primary and secondary patency rates of $75 \%$ and $77 \%$ for two-stage approach, respectively, compared with those of $53 \%$ and $57 \%$ for one-stage approach. ${ }^{70)}$ Ozcan et al. found that those two approaches offered similar patency and a higher complication rate in one-stage approach including thrombosis and hematoma. ${ }^{68)}$ Bashar et al. conducted a systematic review and meta-analysis for eight manuscripts covering 859 fistulas, concluding that the differences between one- and twostage procedures were not statistically significant in terms of overall maturation rate or postoperative complication, with comparable patency rates. ${ }^{71)}$ However, recent reports have indicated better patency with the two-step method, and Mauro et al. found that transecting the basilic vein at the anastomosis and tunneling it superficially led to fewer complications and easier cannulation than elevating the basilic artery in the two-stage procedure. ${ }^{72)}$ In general, reports overall showed that the rate of fistula maturation was higher, but the time to cannulation was longer in the two-stage procedure. ${ }^{65,68,69)}$ Even so, an assessment by Ghaffarian et al. revealed that two-stage procedure was cost-effective with higher patency and lower rates of failure. ${ }^{73)}$ Table 2 showed the summary of main studies so far. ${ }^{29,64-66,68-70,73-75)}$

\section{Complications}

No specific postoperative complications are associated with TBBAVF. ${ }^{14)}$ However, the incidence of complications such as arm edema and access-related bleeding seems higher than with other vascular access, attributable to the extensive surgical mobilization and cannulation in the early period. Woo et al. reported that the incidence of infectious complications was much lower for TBBAVF, at around $2 \%$, compared with $8 \%$ with AVG. ${ }^{76)}$ Beaulieu et al. noted that the most common complication of TBBAVF in the long-term period was stenosis, and the site of stenosis was commonly the confluence of transposition of the basilic vein to the brachial vein. ${ }^{\text {77) Intervention for }}$ such stenosis appears effective, although repeated intervention may be necessary.

\section{TBBAVF in Japan}

Japan has shown one of the highest AVF use, in more than $90 \%$ of the hemodialysis patients. Radiocephalic AVF followed by brachiocephalic AVF is usually created when the superficial cephalic vein is available. AVG is usually the next option, and TBBAVF is not at all common in Japan. Because the KDOQI Clinical Practice Guidelines for Vascular Access place TBBAVF prior to AVG in the order for fistula placement and suitable basilic vein are left unused in many Japanese patients, creation of TBBAVF should be an option before AVG for many Japanese patients. However, considering the low maturation rate and longer time required for cannulation, TBBAVF may be a tertiary or subsequent fistula even in Japan. We found that TBBAVF might achieve maturation for cannulation when the basilic vein is identified as $\geq 3 \mathrm{~mm}$ in diameter preoperatively. The long time until cannulation may cost patients with CVC catheter for a couple of months. Therefore, a one-step approach of TBBAVF rather than a two-step approach may be favorable to reduce catheter time in Japan, although further study is clearly needed. We reported some of TBBAVF with one-step procedure can be used 2 weeks after creation when the fistulas showed good thrill, ${ }^{78)}$ which would be one solution for reduced time for cannulation. One opinion is that the forearm loop AVG is a better option than TBBAVF because the stenosis of confluent site at the basilic vein in TBBAVF ruins the choice of 
Table 2 List of main studies compared between one-stage and two-stage procedures in TBBAVF

\begin{tabular}{|c|c|c|c|c|c|c|c|c|c|}
\hline \multirow{2}{*}{ Authors } & \multirow{2}{*}{ Year } & \multirow{2}{*}{ Study type } & \multirow{2}{*}{ Number } & \multicolumn{2}{|c|}{$\begin{array}{c}\text { Maturation rate } \\
(\%)\end{array}$} & \multicolumn{2}{|c|}{$\begin{array}{c}\text { Secondary patency at } \\
2 \text { years }\end{array}$} & \multirow{2}{*}{ Complication } & \multirow{2}{*}{ Recommendation } \\
\hline & & & & $\begin{array}{l}\text { One } \\
\text { stage }\end{array}$ & $\begin{array}{l}\text { Two } \\
\text { stage }\end{array}$ & $\begin{array}{l}\text { One } \\
\text { stage }\end{array}$ & $\begin{array}{l}\text { Two } \\
\text { stage }\end{array}$ & & \\
\hline \multirow[t]{2}{*}{ El Mallah } & 1998 & Randomized & One stage 20 & 60 & 90 & & & & Two stage \\
\hline & & & Two stage 20 & & & & & & \\
\hline \multirow[t]{3}{*}{ Hossny } & 2003 & Retrospective & One-stage transposition 40 & & & $\begin{array}{c}\text { Transposition } \\
82.8\end{array}$ & $\begin{array}{l}\text { Elevation } \\
\quad 68.4\end{array}$ & $\begin{array}{l}\text { Hematoma: } 26.3 \% \text { in } \\
\text { elevation group }\end{array}$ & \\
\hline & & & One-stage elevation 20 & & & Elevation 70 & & & \\
\hline & & & Two-stage elevation 20 & & & & & & \\
\hline \multirow[t]{2}{*}{ Kakkos } & 2010 & Retrospective & One-stage transposition 76 & $85^{* *}$ & $82^{* *}$ & & & $\begin{array}{l}\text { Complications: higher in } \\
\text { one-stage method }\end{array}$ & Two stage \\
\hline & & & $\begin{array}{l}\text { Two-stage transposition } \\
98(72)^{*}\end{array}$ & & & & & $\begin{array}{l}10 \text { in two-stage group did } \\
\text { not attain second stage }\end{array}$ & \\
\hline \multirow[t]{2}{*}{ Reynolds } & 2011 & Retrospective & One-stage transposition 60 & 77.1 & 90.9 & 41 & 94 & 30 days complications: & Two stage \\
\hline & & & Two-stage tansposition 30 & & & & & similar in both groups & \\
\hline Syed & 2012 & Retrospective & & 79 & 82 & 81 & 27 & & \\
\hline \multirow[t]{2}{*}{ Vrakas } & 2013 & Retrospective & One-stage transposition 65 & 55 & 58 & 57 & 77 & Complications: similar in & Two stage \\
\hline & & & Two-stage elevation 84 & & & & & both groups & \\
\hline \multirow[t]{2}{*}{ Ozcan } & 2013 & Retrospective & $\begin{array}{l}\text { One stage } 47 \text { (basilic vein } \\
>3 \mathrm{~mm} \text { ) }\end{array}$ & 66 & 77 & 98 & 98 & $\begin{array}{l}\text { Complications: higher in } \\
\text { one-stage method }\end{array}$ & Two stage \\
\hline & & & $\begin{array}{l}\text { Two stage } 59 \text { (basilic vein } \\
<3 \mathrm{~mm} \text { ) }\end{array}$ & & & & & & \\
\hline \multirow[t]{2}{*}{ Robertson } & 2013 & Retrospective & One stage 29 & 76 & 84 & $86.2^{* * *}$ & $91.6^{* * *}$ & & One stage \\
\hline & & & Two stage 44 & & & & & & \\
\hline \multirow[t]{2}{*}{ Agarwal } & 2014 & Retrospective & One stage 61 & 90 & 75 & 75 & 71 & Required interventions: & \\
\hline & & & Two stage 83 & & & & & similar in both groups & \\
\hline \multirow[t]{2}{*}{ Kakkos } & 2015 & Randomized & One-stage transposition 9 & 33 & 100 & 44 & 86 & & Two stage \\
\hline & & & Two-stage transposition 7 & & & & & & \\
\hline \multirow[t]{2}{*}{ Ghaffarian } & 2017 & Retrospective & One stage 57 & & & 44 & 73 & $\begin{array}{l}\text { Complications: similar in } \\
\text { both groups }\end{array}$ & Two stage \\
\hline & & & Two stage 74 & & & & & $\begin{array}{l}\text { Two stage was durable } \\
\text { and cost-effective }\end{array}$ & \\
\hline
\end{tabular}

*: 72 out of 98 underwent a second-stage operation; **: including lost or refuse patients; ${ }^{* * *}$ : secondary patency at 6 months

forearm loop AVG. However, it is important to remember that forearm loop AVG shows critical complications such as infection. Even if forearm loop AVG does represent a useful alternative to TBBAVF, the basilic vein should be carefully preserved for a backup fistula.

\section{Conclusion}

TBBAVF offers a valuable autogenous vascular access and represents a good alternative after radial-cephalic and brachial-cephalic configuration. Issues remain regarding TBBAVF, including selection of a one- or two-stage approach, superiority over new artificial graft, and indications for hostile vascular access patients such as those with older age or diabetes, but TBBAVF represents the essential option for a structured approach to optimize autogenous veins for vascular access.

\section{Disclosure Statement}

The authors have neither financial nor other potential conflict to declare.

\section{Author Contributions}

Study conception: JD, OS

Writing: JD

Funding acquisition: OS

Critical review and revision: JD, OS

Final approval of the article: JD, OS

Accountability for all aspects of the work: JD, OS

\section{References}

1) Masakane I, Nakai $S$, Ogata $S$, et al. An overview of regular dialysis treatment in Japan (As of 31 December 2013). Ther Apher Dial 2015; 19: 540-74.

2) Dhingra RK, Young EW, Hulbert-Shearon TE, et al. Type of 
vascular access and mortality in U.S. hemodialysis patients. Kidney Int 2001; 60: 1443-51.

3) Pastan S, Soucie JM, McClellan WM. Vascular access and increased risk of death among hemodialysis patients. Kidney Int 2002; 62: 620-6.

4) Almasri J, Alsawas M, Mainou M, et al. Outcomes of vascular access for hemodialysis: a systematic review and metaanalysis. J Vasc Surg 2016; 64: 236-43.

5) Konner K, Hulbert-Shearon TE, Roys EC, et al. Tailoring the initial vascular access for dialysis patients. Kidney Int 2002; 62: 329-38.

6) Dagher FJ. The upper arm AV hemoaccess: long term followup. J Cardiovasc Surg (Torino) 1986; 27: 447-9.

7) Glass C, Porter J, Singh M, et al. A large-scale study of the upper arm basilic transposition for hemodialysis. Ann Vasc Surg 2010; 24: 85-91.

8) Shibutani S, Obara H, Ono S, et al. Transposed brachiobasilic arteriovenous fistula. Ann Vasc Dis 2013; 6: 164-8.

9) Dukkipati R, de Virgilio C, Reynolds T, et al. Outcomes of brachial artery-basilic vein fistula. Semin Dial 2011; 24: 22030.

10) Sharp R, Cummings M, Childs J, et al. Measurement of vein diameter for Peripherally Inserted Central Catheter (PICC) insertion: an observational study. J Infus Nurs 2015; 38: 351-7.

11) Irfan H, Ooi GS, Kyin MM, et al. Revealing maximal diameter of upper limb superficial vein with an elevated environmental temperature. Int J Chronic Dis 2016; 2016: 8096473.

12) Akoh JA, Paraskeva PP. Review of transposed basilic vein access for hemodialysis. J Vasc Access 2015; 16: 356-63.

13) Tan TW, Farber A. Brachial-basilic autogenous access. Semin Vasc Surg 2011; 24: 63-71.

14) Dix FP, Khan Y, Al-Khaffaf $H$. The brachial artery-basilic vein arterio-venous fistula in vascular access for haemodialysis - a review paper. Eur J Vasc Endovasc Surg 2006; 31: 70-9.

15) Kukita K, Ohira S, Amano I, et al. 2011 update Japanese Society for Dialysis Therapy guidelines of vascular access construction and repair for chronic hemodialysis. Ther Apher Dial 2015; 19 Suppl 1: 1-39.

16) System USRD. 2016 Annual Data Report. Journal [serial online]. 2016; 2 End-stage Renal Disease in the United States. Available from: USRDS Coordinating Center, Ann Arbor, MI, USA.

17) The Japan Society for Transplantation, Japanese Society for Clinical Renal Transplantation. Annual progress report from the Japanese Renal Transplant Registry: number of renal transplantation in 2014 and follow-up survey. Jpn J Transplant 2015; 50: 138-55. (in Japanese)

18) National Kidney Foundation. KDOQI clinical practice guidelines and clinical practice recommendations: hemodialysis adequacy, peritoneal dialysis adequacy and vascular access: update 2006. Am J Kidney Dis 2006; 48 Suppl 1: S1-322.

19) Pisoni RL, Zepel L, Port FK, et al. Trends in US vascular access use, patient preferences, and related practices: an update from the US DOPPS practice monitor with international comparisons. Am J Kidney Dis 2015; 65: 905-15.

20) Fissell RB, Fuller DS, Morgenstern H, et al. Hemodialysis patient preference for type of vascular access: variation and predictors across countries in the DOPPS. J Vasc Access 2013; 14: 264-72.

21) Coentrão L, Van Biesen W, Nistor I, et al. Preferred haemodialysis vascular access for diabetic chronic kidney disease patients: a systematic literature review. J Vasc Access 2015; 16: 259-64.

22) Anaya-Ayala JE, Younes HK, Kaiser CL, et al. Prevalence of variant brachial-basilic vein anatomy and implications for vascular access planning. J Vasc Surg 2011; 53: 720-4.

23) Hyland K, Cohen RM, Kwak A, et al. Preoperative mapping venography in patients who require hemodialysis access: imaging findings and contribution to management. J Vasc Interv Radiol 2008; 19: 1027-33.

24) Ferring $M$, Henderson J, Wilmink A, et al. Vascular ultrasound for the pre-operative evaluation prior to arteriovenous fistula formation for haemodialysis: review of the evidence. Nephrol Dial Transplant 2008; 23: 1809-15.

25) Huber TS, Ozaki CK, Flynn TC, et al. Prospective validation of an algorithm to maximize native arteriovenous fistulae for chronic hemodialysis access. J Vasc Surg 2002; 36: 452-9.

26) Silva MB Jr, Hobson RW 2nd, Pappas PJ, et al. A strategy for increasing use of autogenous hemodialysis access procedures: impact of preoperative noninvasive evaluation. J Vasc Surg 1998; 27: 302-7; discussion, 307-8.

27) Karakayali FY, Sevmis S, Basaran C, et al. Relationship of preoperative venous and arterial imaging findings to outcomes of brachio-basilic transposition fistulae for hemodialysis: a prospective clinical study. Eur J Vasc Endovasc Surg 2008; 35: 208-13.

28) Malovrh M. The role of sonography in the planning of arteriovenous fistulas for hemodialysis. Semin Dial 2003; 16: 299-303.

29) Hossny A. Brachiobasilic arteriovenous fistula: different surgical techniques and their effects on fistula patency and dialysis-related complications. J Vasc Surg 2003; 37: 821-6.

30) Korkut AK, Kosem M. Superficialization of the basilic vein technique in brachiobasilic arteriovenous fistula: surgical experience of 350 cases during 4 years period. Ann Vasc Surg 2010; 24: 762-7.

31) Humphries AL Jr, Colborn GL, Wynn JJ. Elevated basilic vein arteriovenous fistula. Am J Surg 1999; 177: 489-91.

32) Keshelava G, Gvalia K, Kovziridze D, et al. Basilic vein elevation for arteriovenous fistula creation: results of 60 cases following 1 year. Int J Angiol 2016; 25: 219-21.

33) Zielinski CM, Mittal SK, Anderson P, et al. Delayed superficialization of brachiobasilic fistula: technique and initial experience. Arch Surg 2001; 136: 929-32.

34) Pasch AR. A two-staged technique for basilic vein transposition. J Vasc Access 2007; 8: 225-7.

35) Angle N, Chandra A. The two-stage brachial artery-brachial vein autogenous fistula for hemodialysis: an alternative autogenous option for hemodialysis access. J Vasc Surg 2005; 42: 806-10.

36) Wang S, Wang MS, Jennings WC. Basilic elevation transposition may improve the clinical outcomes for superficialization of basilic arteriovenous fistula veins. J Vasc Surg 2017; 65 : 1104-12.

37) Chaudhary FA, Parvez Z. A modified technique of basilic vein transposition for haemodialysis. J Coll Physicians Surg 
Pak 2014; 24: 47-51.

38) Paulson KA, Gordon V, Flynn L, et al. Modified two-stage basilic vein transposition for hemodialysis access. Am J Surg 2011; 202: 184-7.

39) Veeramani M, Vyas J, Sabnis R, et al. Small incision basilic vein transposition technique: a good alternative to standard method. Indian J Urol 2010; 26: 145-7.

40) Paul EM, Sideman MJ, Rhoden DH, et al. Endoscopic basilic vein transposition for hemodialysis access. J Vasc Surg 2010; 51: 1451-6.

41) Arroyo MR, Sideman MJ, Spergel L, et al. Primary and staged transposition arteriovenous fistulas. J Vasc Surg 2008; 47: 1279-83.

42) Lioupis C, Mistry H, Rix T, et al. Comparison among transposed brachiobasilic, brachiobrachial arteriovenous fistulas and Flixene ${ }^{\mathrm{TM}}$ vascular graft. J Vasc Access 2011; 12: 36-44.

43) Voormolen EH, Jahrome AK, Bartels LW, et al. Nonmaturation of arm arteriovenous fistulas for hemodialysis access: a systematic review of risk factors and results of early treatment. J Vasc Surg 2009; 49: 1325-36.

44) Rao RK, Azin GD, Hood DB, et al. Basilic vein transposition fistula: a good option for maintaining hemodialysis access site options? J Vasc Surg 2004; 39: 1043-7.

45) Hakaim AG, Nalbandian M, Scott T. Superior maturation and patency of primary brachiocephalic and transposed basilic vein arteriovenous fistulae in patients with diabetes. J Vasc Surg 1998; 27: 154-7.

46) Coburn MC, Carney WI Jr. Comparison of basilic vein and polytetrafluoroethylene for brachial arteriovenous fistula. J Vasc Surg 1994; 20: 896-902; discussion, 903-4.

47) Matsuura JH, Rosenthal D, Clark M, et al. Transposed basilic vein versus polytetrafluorethylene for brachial-axillary arteriovenous fistulas. Am J Surg 1998; 176: 219-21.

48) Gibson KD, Gillen DL, Caps MT, et al. Vascular access survival and incidence of revisions: a comparison of prosthetic grafts, simple autogenous fistulas, and venous transposition fistulas from the United States Renal Data System Dialysis Morbidity and Mortality Study. J Vasc Surg 2001; 34: 694700.

49) Oliver MJ, McCann RL, Indridason OS, et al. Comparison of transposed brachiobasilic fistulas to upper arm grafts and brachiocephalic fistulas. Kidney Int 2001; 60: 1532-9.

50) Weale AR, Bevis P, Neary WD, et al. A comparison between transposed brachiobasilic arteriovenous fistulas and prosthetic brachioaxillary access grafts for vascular access for hemodialysis. J Vasc Surg 2007; 46: 997-1004.

51) Kakkos SK, Andrzejewski T, Haddad JA, et al. Equivalent secondary patency rates of upper extremity Vectra Vascular Access Grafts and transposed brachial-basilic fistulas with aggressive access surveillance and endovascular treatment. J Vasc Surg 2008; 47: 407-14.

52) Keuter XH, De Smet AA, Kessels AG, et al. A randomized multicenter study of the outcome of brachial-basilic arteriovenous fistula and prosthetic brachial-antecubital forearm loop as vascular access for hemodialysis. J Vasc Surg 2008; 47: 395-401.

53) Chemla ES, Morsy MA. Is basilic vein transposition a real alternative to an arteriovenous bypass graft? A prospective study. Semin Dial 2008; 21: 352-6.

54) Pflederer TA, Kwok S, Ketel BL, et al. A comparison of trans- posed brachiobasilic fistulae with nontransposed fistulae and grafts in the Fistula First era. Semin Dial 2008; 21: 357-63.

55) Torina PJ, Westheimer EF, Schanzer HR. Brachial vein transposition arteriovenous fistula: is it an acceptable option for chronic dialysis vascular access? J Vasc Access 2008; 9: 39 44.

56) Maya ID, O’Neal JC, Young CJ, et al. Outcomes of brachiocephalic fistulas, transposed brachiobasilic fistulas, and upper arm grafts. Clin J Am Soc Nephrol 2009; 4: 86-92.

57) Woo K, Doros G, Ng T, et al. Comparison of the efficacy of upper arm transposed arteriovenous fistulae and upper arm prosthetic grafts. J Vasc Surg 2009; 50: 1405-11.e1-2.

58) Sala Almonacil V, Plaza Martínez A, Zaragozá García J, et al. Comparison between autogenous brachial-basilic upper arm transposition fistulas and prosthetic brachial-axillary vascular accesses for hemodialysis. J Cardiovasc Surg (Torino) 2011; 52: 725-30.

59) Morosetti M, Cipriani S, Dominijanni S, et al. Basilic vein transposition versus biosynthetic prosthesis as vascular access for hemodialysis. J Vasc Surg 2011; 54: 1713-9.

60) Basel H, Ekim H, Odabasi D, et al. Basilic vein transposition fistulas versus prosthetic bridge grafts in patients with endstage renal failure. Ann Vasc Surg 2011; 25: 634-9.

61) Davoudi M, Tayebi P, Beheshtian A. Primary patency time of basilic vein transposition versus prosthetic brachioaxillary access grafts in hemodialysis patients. J Vasc Access 2013; 14: 111-5.

62) Chue KM, Thant KZ, Luo HD, et al. Comprehensive comparison of the performance of autogenous brachial-basilic transposition arteriovenous fistula and prosthetic forearm loop arteriovenous graft in a multiethnic Asian hemodialysis population. BioMed Res Int 2016; 2016: 8693278.

63) Lazarides MK, Georgiadis GS, Papasideris CP, et al. Transposed brachial-basilic arteriovenous fistulas versus prosthetic upper limb grafts: a meta-analysis. Eur J Vasc Endovasc Surg 2008; 36: 597-601.

64) El Mallah S. Staged basilic vein transposition for dialysis angioaccess. Int Angiol 1998; 17: 65-8.

65) Kakkos SK, Tsolakis IA, Papadoulas SI, et al. Randomized controlled trial comparing primary and staged basilic vein transposition. Front Surg 2015; 2: 14.

66) Kakkos SK, Haddad GK, Weaver MR, et al. Basilic vein transposition: what is the optimal technique? Eur J Vasc Endovasc Surg 2010; 39: 612-9.

67) Cooper J, Power AH, DeRose G, et al. Similar failure and patency rates when comparing one- and two-stage basilic vein transposition. J Vasc Surg 2015; 61: 809-16.

68) Ozcan S, Gür AK, Yener AU, et al. Comparison of one- and two-stage basilic vein transposition for arterio-venous fistula formation in haemodialysis patients: preliminary results. Cardiovasc J Afr 2013; 24: 364-8.

69) Agarwal A, Mantell M, Cohen R, et al. Outcomes of singlestage compared to two-stage basilic vein transposition fistulae. Semin Dial 2014; 27: 298-302.

70) Vrakas G, Defigueiredo F, Turner S, et al. A comparison of the outcomes of one-stage and two-stage brachiobasilic arteriovenous fistulas. J Vasc Surg 2013; 58: 1300-4.

71) Bashar K, Healy DA, Elsheikh S, et al. One-stage vs. twostage brachio-basilic arteriovenous fistula for dialysis access: a systematic review and a meta-analysis. PLoS ONE 2015; 
10: e0120154.

72) Mauro R, Pini R, Bianchini Massoni C, et al. A comparison of two surgical techniques for the second stage of brachiobasilic arteriovenous fistula creation. Artif Organs 2017; 41: 539-44.

73) Ghaffarian AA, Griffin CL, Kraiss LW, et al. Comparative effectiveness of one-stage versus two-stage basilic vein transposition arteriovenous fistulas. J Vasc Surg 2017; Sep 21. [Epub ahead of print]

74) Syed FA, Smolock CJ, Duran C, et al. Comparison of outcomes of one-stage basilic vein transpositions and two-stage basilic vein transpositions. Ann Vasc Surg 2012; 26: 852-7.

75) Reynolds TS, Zayed M, Kim KM, et al. A comparison between one- and two-stage brachiobasilic arteriovenous fistulas. J Vasc Surg 2011; 53: 1632-8; discussion, 1639.

76) Woo K, Farber A, Doros G, et al. Evaluation of the efficacy of the transposed upper arm arteriovenous fistula: a single institutional review of 190 basilic and cephalic vein transposition procedures. J Vasc Surg 2007; 46: 94-9; discussion, 100.

77) Beaulieu MC, Gabana C, Rose C, et al. Stenosis at the area of transposition - an under-recognized complication of transposed brachiobasilic fistulas. J Vasc Access 2007; 8: 268-74.

78) Matsumoto H, Yamamoto E, Kamiya C, et al. Early use of brachial-basilic arteriovenous fistula. J Vasc Access 2012; 13: 251-5. 